\title{
Corporate Social Responsibility Disclosure, Debt Financing Costs, and Innovation Capacity
}

\author{
Yang Miao, ${ }^{1}$ Xiaoxue Zhou ${ }^{D},{ }^{2}$ and Xin Dai $\mathbb{D D}^{3}$ \\ ${ }^{1}$ Dongbei University of Finance and Economics, Dalian, China \\ ${ }^{2}$ Dalian University of Technology, Dalian, China \\ ${ }^{3}$ Dalian Medical University, Dalian, China \\ Correspondence should be addressed to Xiaoxue Zhou; zhouxiaoxue1990@foxmail.com and Xin Dai; sqtya@163.com
}

Received 24 July 2021; Revised 15 August 2021; Accepted 17 August 2021; Published 13 September 2021

Academic Editor: Daqing Gong

Copyright (C) 2021 Yang Miao et al. This is an open access article distributed under the Creative Commons Attribution License, which permits unrestricted use, distribution, and reproduction in any medium, provided the original work is properly cited.

The challenges of financing have been troubling the development of Chinese enterprises, especially private enterprises. This paper aims to examine the antecedents and consequences of debt financing costs. Drawing on a sample of Chinese A-share listed companies in Shanghai and Shenzhen from 2009 to 2018, the study examined the relationship between corporate social responsibility disclosure, debt financing costs, and innovation capacity. This paper found that the quality of CSR disclosure is negatively related to the cost of debt financing and examined the situational differences in the impact of CSR disclosure quality under different property rights, different disclosure forms, and different forensic effects. Moreover, it is found that the negative effect of CSR disclosure quality on debt financing cost helps to induce the innovation capacity of enterprises. The findings of this paper have certain reference value for corporate improvement of social responsibility disclosure.

\section{Introduction}

The problem of difficult and expensive financing has been troubling the development of Chinese enterprises, especially private enterprises. After the reform and opening up, China has been implementing various financial reform policies in an attempt to alleviate this real problem, but up to now, the problem of financing cost for enterprises is still one of the important factors that restrict the development of enterprises. Consequently, one of the central concerns of both academics and practitioners is how to effectively reduce the financing costs of enterprises. In terms of corporate financing channels, the debt financing method is one of the important ways for enterprises to obtain external funds. Wang Yuntong and Jiang Fuxiu [1] point out that with regard to countries with a low level of marketization, debt financing is even the most important way of financing for enterprises.

In fact, the issue of the structure and cost of debt financing of firms has been one of the hot topics of research in the field of corporate finance. Initially, the research framework of scholars on the cost of corporate debt financing was limited to the efficient market hypothesis, which argued that under perfect market conditions, the cost of corporate financing should be a function of corporate cash flow risk and its premium [2]. Following the development of new institutional economics, theories such as agency theory and information asymmetry theory continue to break the structure of traditional theoretical assumptions and establish theories that have more explanatory power on reality and explain the cost of debt financing of modern enterprises accordingly. Following the continuous improvement of China's marketization level, the problem of enterprise financing has gradually become one of the important factors restricting China's economic development, with an increasing number of scholars examining the problem of debt financing cost of Chinese enterprises based on the special institutional background of China. Most of the studies have been conducted to analyze the debt financing cost of firms from the perspective of macroenvironment such as legal environment, interest rate market reform [3], industry environment [4], and reform of security right system [5], while 
some studies are based on microperspective, from corporate governance [1], executive characteristics, and cross-ownership M\&A, among other directions.

In fact, corporate social responsibility (CSR) disclosure can send a good signal to creditors and can divert stakeholders' attention from negative corporate issues [6]. The higher the quality of CSR information disclosure, the more it helps to establish a good corporate image to creditors, which in turn reduces the debt financing cost of enterprises. However, the relationship between CSR disclosure and debt financing cost has not been fully explored. Accordingly, this paper aims to examine the factors influencing the cost of corporate debt financing from the perspective of CSR information disclosure.

This paper empirically tests the relationship between CSR disclosure quality and the cost of debt financing based on a sample of 5988 observations of Chinese A-share listed companies in Shanghai and Shenzhen from 2009 to 2018, where the research finds that, holding other conditions constant, CSR disclosure quality is negatively related to the cost of debt financing. The impact of social responsibility information disclosure quality on the cost of debt financing is found to be greater in the sample group of non-stateowned enterprises compared to the sample group of stateowned enterprises by differentiating the nature of ownership. The impact of social responsibility information disclosure quality on the cost of debt financing is found to be greater in the sample group of voluntary disclosure compared to the sample group of voluntary disclosure. The impact of social responsibility information disclosure quality on the cost of debt financing is not significantly different between the assurance and nonassessment groups. As for the economic consequences, the study finds that the quality of social responsibility disclosure can enhance corporate innovation by reducing the cost of corporate debt financing.

\section{Literature Review and Research Hypothesis}

According to information asymmetry and principal-agent theory, in market economic activities, external users have different levels of knowledge about various types of information, and agents provide incomplete and false financial information for their private interests, resulting in the loss of benefits to external information users due to poor decision making. As relevant studies showed, nonfinancial information disclosure is important for reducing information asymmetry and agency problems, and the disclosure of nonfinancial information can enhance information communication between firms and investors to reduce additional expenses. The fulfillment of social responsibility and the disclosure of the report to the public has a strategic purpose and is a nonfinancial information disclosure strategy for enterprises, which can invariably change the perception of the enterprise's stakeholders, and the fulfillment of social responsibility sends a good signal to the outside world.

Based on the signaling theory, enterprises should fully and fairly disclose their operating conditions to the public, which can effectively alleviate the information asymmetry between enterprises and creditors, avoid adverse selection, and enable debtors to obtain sufficient information to objectively and fairly assess the solvency of enterprises. In addition, the cost of debt financing is the return required by the creditor to lend funds and depends on the creditor's perceived risk of debtor repayment. Companies applying for loans from banks shall provide comprehensive information on products, market, technology and capital, etc. Banks judge their solvency, amount, and cost based on the information provided by companies. As stated by information disclosure theory, the information asymmetry of a company depends largely on the information policy and information environment. A complete information disclosure policy and adequate information disclosure can increase information transparency, reduce information asymmetry of a company, and thus reduce financing costs. An increase in the level of external disclosure by firms can directly reduce the level of information asymmetry and can have a beneficial effect on stock popularity and external financing costs [7], and firms with social responsibility disclosure information are more likely to obtain bank loans [8]. By disclosing CSR information, information asymmetry can be mitigated, which can reduce the cost of external financing for firms [9]. Previously mentioned, CSR compliance and external disclosure behavior is a strategic behavior for companies and can invariably change the understanding and awareness of internal and external stakeholders of companies. The social responsibility fulfillment can send a good signal to the stakeholders and can further divert their attention from the "negative" problems that the company is facing.

In the market economy transactions, various interested parties differ in the degree of access to and understanding of relevant information. As social responsibility has become an important part of normal business operation, CSR information disclosure can provide more information related to business operation to the outside world. On the basis of stakeholder perspective, enterprises are essentially composed of various stakeholders, with the goal of creating wealth and value for all stakeholders, rather than simply maximizing shareholders' interests. The resources essential to the survival and growth of the enterprise are invested by the various stakeholders and do not include only the equity capital invested by shareholders. By fulfilling and disclosing social responsibility information with high quality, companies can gain the support of stakeholders and thus obtain various resources to improve their competitive advantage and increase their corporate value. From a social exchange perspective, by undertaking and disclosing social responsibility information, companies can exchange with their stakeholders and change their perceptions and expectations of future performance by sending high-quality signals, thus achieving their strategic objectives, and obtaining lower debt financing costs is one of the important manifestations of their strategic implementation results. Due to the external pressure perspective, companies are driven by external legitimacy pressure to actively perform and disclose social responsibility information with high quality so as to reduce various systemic risks of the enterprise [10]. As Shen Hongtao [11] points out, corporate disclosure behavior can be seen as a function of the social and political pressures faced by enterprises, and the quality of social responsibility disclosure is improved when 
enterprises are under greater pressure for legitimacy. In other words, there is pressure for legitimacy to make social responsibility disclosure consciously and actively, and to send better signals to the outside world by improving the quality of disclosure. In general, as the quality of a company's social responsibility information disclosure is higher, the degree of its social responsibility deficiency is correspondingly lower [12]. He et al. [12] found that the degree of financing constraints was significantly lower for disclosing companies relative to companies that did not disclose social responsibility reports, while the higher the quality of social responsibility information disclosure, the lower the degree of financing constraints for companies in the sample of disclosing companies.

As shown above, the better the quality of social responsibility information disclosed by enterprises, the more it can reduce the degree of information asymmetry between enterprises and financial institutions, reduce the information search and processing costs of banks and other financial institutions, and thus help financing institutions to accurately assess the future business risks and solvency faced by enterprises. Accordingly, this paper argues that companies with high quality of social responsibility information disclosure can reduce banks' assessment of their future risk, and banks are more inclined to grant loans to such companies and give them lower interest rates. Consequently, as the higher quality of social responsibility information disclosed by enterprises, it means that the more reliable signals they release to the outside world, creditors can accurately assess the actual debt servicing and profitability of enterprises accordingly, thus enabling them to obtain debt financing at a lower cost. Based on this, this paper proposes the following research hypothesis.

H1. Other things being equal, the quality of CSR disclosure is negatively related to the cost of debt financing.

\section{Research Design}

3.1. Sample Selection and Data Sources. For this paper, 2009-2018 Chinese listed companies in Shanghai and Shenzhen A-shares are selected as the research sample, and 2009 is used as the starting point for sample selection mainly because Runling Global only started to disclose the social responsibility report score of listed companies in 2009. The research data for this paper are obtained from two databases, including financial data from the Guotaian database (CSMAR) and CSR information disclosure data from RKS. With reference to previous research paradigms, the following sample of studies was excluded from this paper: (1) exclude listed companies in the financial and insurance industries; (2) exclude ST and $*$ ST companies; (3) exclude samples with missing variables. To alleviate the interference of extreme values on the empirical results, the continuous variables are subjected to the upper and lower $1 \%$ tailshrinking process, and a total of 5988 observed samples from 2009 to 2018 are finally obtained.

3.2. Variable Definition and Model Design. To test the impact of social responsibility information disclosure on the cost of corporate debt financing, the following research model is constructed in this paper, as shown in

$$
\text { Debt_ } C_{i, t}=\alpha_{0}+\alpha_{1} \text { CSR }_{-} Q_{i, t}+\sum \alpha_{i} \operatorname{Control}_{i, t}+\varepsilon_{i, t} .
$$

In the above equation, Control is the control variable. This paper focuses on the coefficient $\alpha 1$ in equation (1). If $\alpha 1<0$ and is significant in the model, it means that the higher the quality of CSR disclosure, the lower the cost of corporate debt financing and supports the research hypothesis of this paper, vice versa.

3.2.1. Explained Variables. Debt_C, the explanatory variable, is a measure of the cost of debt financing. Drawing on the method of Qian et al. [5], we use corporate interest expense divided by total debt to measure the cost of debt financing, where the interest expense data are obtained from the breakdown of interest expense under the corporate finance expense account.

3.2.2. Explanatory Variables. Following the method of Guo et al. [13], we applied RKS score on CSR reports to measure the quality of CSR disclosure (CSR_Q). The score rates the status of CSR disclosure in four dimensions: overall (M), content $(\mathrm{C})$, technical $(\mathrm{T})$, and industry (I), respectively. The overall $(\mathrm{M})$ dimension is evaluated from the perspectives of corporate strategy, corporate governance, and stakeholders, with a total score of 30 points; the content $(\mathrm{C})$ dimension is evaluated from the perspectives of performance, human rights, environment, customer, and community involvement, with a total score of 45 points; the technical (T) dimension is evaluated from the perspectives of comparability, credibility, standardization, innovation, and transparency, with a total score of 15 points; and the industry (I) dimension considers the special conditions of some industries, with a total score of 10 points, and the total score of the four items is 100 points.

3.2.3. Control Variables. Drawing on the studies of Zhou et al. [14], Wang and Jiang [1], Qian Xuesong et al. [5], and Pan Ailing et al, in this paper, we select the nature of property rights (SOE), dual office (Duality), proportion of independent directors (Indsize), shareholding of the first largest shareholder (Top1), audit quality (Aud_Top10), enterprise size (Size), return on assets (ROA), gearing ratio (Lev), enterprise growth (Growth), tangible assets ratio (Tangi), operating cash flow (CF), and firm loss (Loss) were used as control variables. Additionally, industry and year dummy variables are included in this paper to control for industry fixed effects and year fixed effects. The specific variables are defined as shown in Table 1.

\section{Empirical Results and Analysis}

4.1. Descriptive Statistics. In Table 2, descriptive statistics of the main variables of this chapter are reported. The mean value of debt financing cost (Debt_C) is 0.024 and the median value is 0.023 , indicating that the average debt financing cost of the sample companies is $2.4 \%$. The mean value of CSR disclosure quality (CSR_Q) is 34.30 , and the 
Table 1: Definition of variables.

\begin{tabular}{|c|c|c|c|}
\hline Variable type & Variable name & $\begin{array}{l}\text { Variable } \\
\text { symbols }\end{array}$ & Variable definition \\
\hline $\begin{array}{l}\text { Explained } \\
\text { variables }\end{array}$ & Cost of debt financing & Debt_C & Corporate interest expense divided by total liabilities \\
\hline $\begin{array}{l}\text { Explanatory } \\
\text { variables }\end{array}$ & $\begin{array}{l}\text { Quality of social } \\
\text { responsibility disclosure }\end{array}$ & CSR_Q & Total rating of RKS CSR report \\
\hline \multirow{14}{*}{$\begin{array}{l}\text { Control } \\
\text { variables }\end{array}$} & Nature of property rights & SOE & State-owned shareholders take 1 , non-state-owned shareholders take 0 \\
\hline & Two positions in one & Duality & $\begin{array}{c}\text { Take } 1 \text { if the chairman and general manager are the same person, } \\
\text { otherwise take } 0\end{array}$ \\
\hline & $\begin{array}{l}\text { Percentage of independent } \\
\text { directors }\end{array}$ & Indsize & $\begin{array}{c}\text { Ratio of the number of independent directors to the total number of } \\
\text { board of directors }\end{array}$ \\
\hline & $\begin{array}{l}\text { Shareholding of the first } \\
\text { largest shareholder }\end{array}$ & Top1 & Shareholding ratio of the largest shareholder \\
\hline & Audit quality & Aud_Top10 & 1 for the top 10 audit firms, otherwise 0 \\
\hline & Enterprise size & Size & Natural logarithm of the total assets of the company \\
\hline & Return on assets & ROA & Net profit divided by the total assets of the company \\
\hline & Gearing ratio & Lev & Total liabilities divided by total assets \\
\hline & Enterprise growth & Growth & Growth rate of operating income \\
\hline & Tangible assets ratio & Tangi & $\begin{array}{l}\text { The difference between total assets and intangible assets divided by total } \\
\text { assets }\end{array}$ \\
\hline & Operating cash flow & $\mathrm{CF}$ & Operating cash flow divided by total assets \\
\hline & Corporate losses & Loss & Negative net income is taken as 1 , otherwise it is zero \\
\hline & Year & Year & Set annual dummy variables according to the time year \\
\hline & Industry & Ind & $\begin{array}{l}\text { According to the } 2012 \text { industry classification standard of the securities } \\
\text { and futures commission, the industry dummy variables are set by } \\
\text { excluding the financial industry and using agriculture, forestry, animal } \\
\text { husbandry, and fishery as the benchmark }\end{array}$ \\
\hline
\end{tabular}

TABLE 2: Descriptive statistics of variables.

\begin{tabular}{|c|c|c|c|c|c|c|}
\hline Variable name & Observed values & Mean & Standard deviation & 1/4 quartile & Median & $3 / 4$ quartile \\
\hline Debt_C & 5988 & 0.024 & 0.013 & 0.014 & 0.023 & 0.033 \\
\hline CSR_Q & 5988 & 34.300 & 22.040 & 18.920 & 26.290 & 56.290 \\
\hline SOE & 5988 & 0.510 & 0.500 & 0.000 & 1.000 & 1.000 \\
\hline Duality & 5988 & 0.201 & 0.401 & 0.000 & 0.000 & 0.000 \\
\hline Indsize & 5988 & 0.377 & 0.059 & 0.333 & 0.364 & 0.429 \\
\hline Top1 & 5988 & 0.361 & 0.016 & 0.240 & 0.345 & 0.468 \\
\hline Aud Top10 & 5988 & 0.564 & 0.496 & 0.000 & 1.000 & 1.000 \\
\hline Size & 5988 & 22.980 & 1.404 & 21.980 & 22.810 & 23.790 \\
\hline $\mathrm{ROA}$ & 5988 & 0.025 & 0.125 & 0.012 & 0.030 & 0.055 \\
\hline Lev & 5988 & 0.527 & 0.217 & 0.392 & 0.527 & 0.656 \\
\hline Growth & 5988 & 0.433 & 6.159 & 0.00278 & 0.130 & 0.309 \\
\hline Tangi & 5988 & 0.916 & 0.110 & 0.904 & 0.953 & 0.978 \\
\hline $\mathrm{CF}$ & 5988 & 0.039 & 0.073 & 0.003 & 0.040 & 0.080 \\
\hline Loss & 5988 & 0.100 & 0.300 & 0.000 & 0.000 & 0.000 \\
\hline
\end{tabular}

values of the $1 / 4$ th, median, and $3 / 4$ th quartiles are 18.92 , 26.29 , and 56.29, respectively, indicating that the sample companies' social responsibility information disclosure quality score is low overall. As for the control variables, the mean value of the nature of property rights (SOE) is 0.51 , indicating that the proportion of state-owned enterprises and non-state-owned enterprises in the study sample is even; the mean value of duality (Duality) is 0.201 , indicating that on average, $1 / 5$ of the sample companies have CEOs with two positions; the mean value of the proportion of independent directors (Indsize) is 0.377 , and the $1 / 4$ quartile is 0.333 , indicating that, in an average sense, most of the listed companies fulfill the Guidance on the Establishment of Independent Director System in Listed Companies. The mean value of firm loss (Loss) is 0.1 , indicating that $10 \%$ of the sample firms have profit losses. Moreover, the means and medians of the remaining control variables such as the first largest shareholder's shareholding (Top1), audit quality (Aud_Top10), firm size (Size), return on assets (ROA), gearing (Lev), firm growth (Growth), tangible asset ratio (Tangi), and operating cash flow (CF) are similar to those of Zhou et al. [14], Wang and Jiang [1], Qian et al. [5], and other statistics which are similar. 
4.2. Correlation Analysis. In Table 3, the correlation coefficient matrix between the main variables of this paper is presented, where the Pearson correlation coefficient is shown in the lower left corner of the matrix and Spearman correlation coefficient is shown in the upper right corner. From the table, it can be found that the Pearson correlation coefficient between social responsibility disclosure quality (CSR_Q) and debt financing cost (Debt_C) is -0.034 and significant at the $5 \%$ level, and the Spearman correlation coefficient is -0.059 and significant at the $1 \%$ level, which provides preliminary supporting evidence for the research hypothesis of this paper. Moreover, the correlation coefficients among the control variables were all below 0.5 , indicating that no serious problem of multicollinearity existed among the model variables.

4.3. Basic Regression Analysis. Prior to the multiple linear regression analysis, this paper used variance inflation factor (VIF) to diagnose the regression model for multiple cointegration, and the diagnostic results found that the variance inflation factor (VIF) of all variables was less than 10, further indicating that there was no serious multiple cointegration problem among the study variables. Aiming to control the possible heteroskedasticity problem in the model, this paper uses heteroskedasticity robust standard errors for regression estimation.

The results of the multiple linear regression of the empirical model of this paper are reported in Table 4, where column (1) presents the regression results after controlling for industry and year fixed effects only, and the regression coefficient of the explanatory variable CSR_Q of social responsibility disclosure quality is -0.0002 and significant at the $1 \%$ level, with an adjusted $R^{2}$ of 0.147 . Column (2) presents the regression results following the inclusion of all control variables, which shows that the regression coefficient of the explanatory variable CSR_Q is -0.0001 and is still significant at the $1 \%$ level, with an adjusted $R^{2}$ of 0.182 , indicating that the higher the quality of CSR disclosure, the lower the cost of debt financing, which is consistent with the research hypothesis of this paper. For the control variables, the nature of ownership (SOE) coefficient is significantly negative at the $10 \%$ level, indicating that it is cheaper for state-owned enterprises to obtain debt financing relative to non-state-owned enterprises. The coefficients of audit quality (Aud_Top10), firm size (Size), and firm growth (Growth) are significantly negative at the $1 \%, 1 \%$, and $5 \%$ levels, respectively, indicating that the higher the audit quality, the larger the enterprise size, and the better the growth of the enterprise, the lower the cost of debt financing for the enterprise. The coefficients of gearing (Lev) and corporate loss (Loss) are significantly positive at the $1 \%$ level, indicating that the higher the gearing ratio, the greater the cost of debt financing for loss-making enterprises.

4.4. Heterogeneity Analysis. Based on the analysis of the nature of property rights, aiming to examine the sensitivity difference of the impact of CSR information disclosure quality on debt financing cost under different property rights nature, this paper divides the research sample into nonstate-owned enterprises group and state-owned enterprises group for group testing. The regression results are shown in Table 5. In the non-state-owned enterprise sample group, the regression coefficient of social responsibility information disclosure quality (CSR_Q) is -0.00019 and significant at the $1 \%$ level. The coefficient of regression of social responsibility disclosure quality (CSR_Q) is -0.00005 and significant at the $1 \%$ level in the sample group of SOEs, which indicates that the effect of CSR disclosure quality on the cost of debt financing is significant in both SOEs and non-SOEs. Moreover, in this paper, the difference test of the coefficients between groups is conducted using the seemingly uncorrelated model (SUR method), and the Chi2 value of 24.96 and the Prob > chi2 value of 0.000 are obtained, which are significant at the $1 \%$ level, indicating that there is a significant difference between the regression coefficients of the two groups, i.e., compared to the sample group of stateowned enterprises, the impact of social responsibility information disclosure quality on debt financing cost in the sample group of non-state-owned enterprises group is greater. Possibly, the reason is that creditors tend to be more cautious in judging non-SOEs than the institutional advantages of SOEs and rely more on the external disclosure information of non-SOEs to start the analysis about the enterprise's operation and solvency; therefore, the effect of CSR information disclosure quality on the cost of debt financing is more evident in the sample group of non-SOEs.

Based on the analysis of the disclosure forms, the external disclosure forms of CSR information include two types of disclosures, namely, the required disclosure and the voluntary disclosure. In addition, with a view to examining whether there is a sensitivity difference in the impact of CSR information disclosure quality on the cost of debt financing under different disclosure forms, this paper divides the research sample into a group test for the regulatory disclosure group and a voluntary disclosure group. As shown in Table 6, the regression coefficient of social responsibility information disclosure quality (CSR_Q) is -0.00014 and significant at the $1 \%$ level in the sample group of required disclosure; in the sample group of voluntary disclosure, the regression coefficient of social responsibility information disclosure quality (CSR_Q) is -0.00007 and significant at the $1 \%$ level, which indicates that the effect of CSR disclosure quality on the cost of debt financing is significant across firms with different forms of disclosure. Moreover, this paper uses the seemingly uncorrelated model (SUR method) to test the difference between the coefficients of the groups and obtains Chi2 value of 4.71 and Prob > chi2 value of 0.03 , which are significant at the $5 \%$ level, indicating that there is a significant difference between the regression coefficients of the two groups; that is, the impact of the quality of social responsibility disclosure on the cost of debt financing is greater in the sample group of the required disclosure compared to the sample group of voluntary disclosure. A study by Quan et al. [6] found that CSR disclosure often manifests itself as a self-interest tool, and Chinese firms tend to hide and divert public attention from other corporate misconduct through the fulfillment and disclosure of social 
TABLE 3: Correlation analysis of variables

\begin{tabular}{|c|c|c|c|c|c|c|c|}
\hline Variable name & Debt_C & CSR_Q & SOE & Duality & Indsize & Top1 & Aud_Top 10 \\
\hline Debt_C & 1 & $-0.059^{* * *}$ & $0.060^{* * *}$ & -0.021 & $-0.039^{* *}$ & $-0.053^{* * *}$ & $-0.061^{* * *}$ \\
\hline CSR_Q & $-0.034^{* *}$ & 1 & $0.182^{* * *}$ & $-0.080^{* * *}$ & -0.014 & $0.165^{* * *}$ & 0.003 \\
\hline SOE & $0.0493^{* * *}$ & $0.189^{* * *}$ & 1 & $-0.295^{* * *}$ & -0.021 & $0.302^{* * *}$ & $0.048^{* * *}$ \\
\hline Duality & -0.018 & $-0.086^{* * *}$ & $-0.295^{* * *}$ & 1 & $0.099^{* *}$ & $-0.098^{* * *}$ & -0.002 \\
\hline Indsize & $-0.042^{* *}$ & -0.004 & -0.008 & $0.096^{* * *}$ & 1 & $0.054^{* * *}$ & 0.021 \\
\hline Top1 & $-0.054^{* * *}$ & $0.155^{* * *}$ & $0.293^{* * *}$ & $-0.096^{* * *}$ & $0.080^{* * *}$ & 1 & $0.108^{* * *}$ \\
\hline Aud_Top10 & $-0.062^{* * *}$ & -0.016 & $0.048^{* * *}$ & -0.002 & $0.031^{*}$ & $0.108^{* * *}$ & 1 \\
\hline Size & $-0.030^{*}$ & $0.169^{* * *}$ & $0.366^{* * *}$ & $-0.151^{* * *}$ & $0.086^{* * *}$ & $0.309^{* * *}$ & $0.184^{* * *}$ \\
\hline ROA & $-0.140^{* * *}$ & $0.229^{* * *}$ & 0.011 & -0.019 & $-0.033^{*}$ & $0.050^{* * *}$ & $0.026^{*}$ \\
\hline Lev & $0.121^{* * *}$ & -0.014 & $0.199^{* * *}$ & $-0.082^{* * *}$ & $0.0537^{* * *}$ & $0.085^{* * *}$ & 0.011 \\
\hline Growth & $-0.029^{*}$ & 0.014 & $-0.036^{* *}$ & -0.001 & 0.004 & $0.032^{*}$ & 0.015 \\
\hline Tangi & -0.020 & $0.099^{* * *}$ & $0.125^{* * *}$ & $-0.075^{* * *}$ & 0.014 & $0.122^{* * *}$ & -0.019 \\
\hline $\mathrm{CF}$ & $0.089^{* * *}$ & $0.130^{* * *}$ & $0.057^{* * *}$ & $-0.045^{* * *}$ & $-0.036^{* *}$ & $0.108^{* * *}$ & $0.079^{* * *}$ \\
\hline Loss & $0.183^{* * *}$ & $-0.328^{* * *}$ & 0.004 & 0.017 & 0.011 & $-0.060^{* * *}$ & $-0.038^{* *}$ \\
\hline Variable name & Size & $\mathrm{ROA}$ & Lev & Growth & Tangi & $\mathrm{CF}$ & Loss \\
\hline Debt_C & 0.009 & $-0.232^{* * *}$ & $0.114^{* * *}$ & $-0.158^{* * *}$ & -0.016 & $0.091^{* * *}$ & $0.170^{* * *}$ \\
\hline CSR_Q & $0.196^{* * *}$ & $0.397^{* * *}$ & 0.003 & $0.077^{* * *}$ & $0.151^{* * *}$ & $0.173^{* * *}$ & $-0.331^{* * *}$ \\
\hline $\mathrm{SOE}$ & $0.363^{* * *}$ & $-0.134^{* * *}$ & $0.255^{* * *}$ & $-0.123^{* * *}$ & $0.175^{* * *}$ & $0.070^{* * *}$ & 0.004 \\
\hline Duality & $-0.157^{* * *}$ & $0.048^{* * *}$ & $-0.108^{* * *}$ & $0.065^{* * *}$ & $-0.090^{* * *}$ & $-0.048^{* * *}$ & 0.017 \\
\hline Indsize & $0.042^{* *}$ & $-0.032^{*}$ & $0.035^{* *}$ & -0.008 & 0.004 & $-0.038^{* *}$ & 0.012 \\
\hline Top1 & $0.273^{* * *}$ & $0.050^{* * *}$ & $0.112^{* * *}$ & $-0.053^{* * *}$ & $0.143^{* * *}$ & $0.119^{* * *}$ & $-0.060^{* * *}$ \\
\hline Aud_Top10 & $0.165^{* * *}$ & $0.046^{* * *}$ & 0.015 & $-0.0343^{* *}$ & -0.013 & $0.082^{* * *}$ & $-0.038^{* *}$ \\
\hline Size & 1 & $-0.028^{*}$ & $0.469^{* * *}$ & -0.003 & $0.150^{* * *}$ & $0.072^{* * *}$ & $-0.090^{* * *}$ \\
\hline ROA & $0.078^{* * *}$ & 1 & $-0.420^{* * *}$ & $0.298^{* * *}$ & $-0.070^{* * *}$ & $0.342^{* * *}$ & $-0.519^{* * *}$ \\
\hline Variable name & Size & $\mathrm{ROA}$ & Lev & Growth & Tangi & $\mathrm{CF}$ & Loss \\
\hline Lev & $0.350^{* * *}$ & $-0.474^{* * *}$ & 1 & $-0.047^{* * *}$ & $0.261^{* * *}$ & $-0.169^{* * *}$ & $0.182^{* * *}$ \\
\hline Growth & 0.014 & 0.014 & 0.019 & 1 & $-0.081^{* * *}$ & 0.011 & $-0.267^{* * *}$ \\
\hline Tangi & $0.094^{* * *}$ & 0.002 & $0.170^{* * *}$ & -0.020 & 1 & $-0.085^{* * *}$ & $-0.031^{*}$ \\
\hline $\mathrm{CF}$ & $0.071^{* * *}$ & $0.156^{* * *}$ & $-0.153^{* * *}$ & -0.022 & $-0.0740^{* * *}$ & 1 & $-0.159^{* * *}$ \\
\hline Loss & $-0.096^{* * *}$ & $-0.432^{* * *}$ & $0.207^{* * *}$ & -0.025 & 0.001 & $-0.141^{* * *}$ & 1 \\
\hline
\end{tabular}

${ }^{*} p<0.05,{ }^{* *} p<0.01$, and ${ }^{* * *} p<0.001$

responsibility. Consequently, enterprises that voluntarily disclose are more likely to do so out of consideration for their own interests and therefore show more significant impact effects.

Analysis with respect to the effect of assurance: The SSE, SZSE, and SFC have been encouraging companies to disclose social responsibility assurance reports. Theoretically, an authenticated CSR report is more reliable and therefore more likely to gain the trust of corporate stakeholders. For this reason, the paper further examines whether there is a significant difference in the impact of social responsibility disclosure quality on the cost of debt financing between firms subject to assurance and those not subject to assurance. With reference to the method of Zhou et al. [14], this paper divides the study sample into an unaccredited group and an accredited group based on whether the CSR report has been accredited by a professional third-party authority, and develops group regressions. As shown in Table 7, the regression coefficient of social responsibility disclosure quality (CSR_Q) is -0.00011 and significant at the $1 \%$ level in the nonforensic sample group and the regression coefficient of social responsibility disclosure quality (CSR_Q) is -0.00012 and significant at the $10 \%$ level in the forensic sample group, which indicates that the effect of CSR disclosure quality on the cost of debt financing is significantly present in different forensic scenarios. Taking further, this paper used the seemingly uncorrelated model (SUR method) to test the difference between the coefficients of the groups and obtained a Chi2 value of 0.01 and a Prob $>$ chi2 value of 0.932 , indicating that there was no significant difference between the regression coefficients of the two groups. Two possible reasons: one is that given the small sample size of the current professional third-party authority assurance, this may have led to some bias in the regression results of the assurance group in this paper; the other may mean that stakeholders, especially creditors, have not yet paid enough attention to the CSR assurance reports, thus leading to the fact that the social responsibility reports subject to the assurance do not show a greater impact.

\section{Robustness Test}

5.1. Measurements of Replacement Debt Financing Costs. In this paper, referring to the method of Xuesong [5], we replace the measure of debt financing cost by using corporate finance costs divided by total debt, and the sign of the variable is set to Debt_C1. Prior to the regression analysis, the model is retested for multicollinearity and it is found that the variance inflation factor (VIF) of all variables in the model is less than 10 , indicating that the regression model does not have serious multicollinearity covariance problem. Table 8 presents the regression results after replacing the measure of debt financing cost, where column (1) presents the regression results after 
TABle 4: Basic multiple linear regression results.

\begin{tabular}{|c|c|c|}
\hline Variable name & $\begin{array}{c}(1) \\
\text { Debt_C }\end{array}$ & $\begin{array}{c}(2) \\
\text { Debt_C }\end{array}$ \\
\hline CSR_Q & $\begin{array}{c}-0.0002^{* * *} \\
(-13.82)\end{array}$ & $\begin{array}{c}-0.0001^{* * *} \\
(-8.22)\end{array}$ \\
\hline SOE & & $\begin{array}{c}-0.0007^{*} \\
(-1.70) \\
\end{array}$ \\
\hline Duality & & $\begin{array}{l}0.0004 \\
(0.96)\end{array}$ \\
\hline Indsize & & $\begin{array}{r}-0.0017 \\
(-0.63) \\
\end{array}$ \\
\hline Top1 & & $\begin{array}{c}-0.0069^{* * *} \\
(-6.03)\end{array}$ \\
\hline Aud_Top10 & & $\begin{array}{c}-0.0010^{* * *} \\
(-3.18)\end{array}$ \\
\hline Size & & $\begin{array}{c}-0.0004^{* * *} \\
(-2.68) \\
\end{array}$ \\
\hline ROA & & $\begin{array}{c}-0.0012 \\
(-0.30)\end{array}$ \\
\hline Lev & & $\begin{array}{c}0.0081^{* * *} \\
(5.42) \\
\end{array}$ \\
\hline Growth & & $\begin{array}{c}-0.0000^{* *} \\
(-2.38)\end{array}$ \\
\hline Tangi & & $\begin{array}{c}-0.0017 \\
(-0.95) \\
\end{array}$ \\
\hline $\mathrm{CF}$ & & $\begin{array}{c}0.0149^{* * *} \\
(5.30) \\
\end{array}$ \\
\hline Loss & & $\begin{array}{c}0.0038^{* * *} \\
(4.55) \\
\end{array}$ \\
\hline _cons & $\begin{array}{c}0.0371^{* * *} \\
(26.10) \\
\end{array}$ & $\begin{array}{c}0.0438^{* * *} \\
(11.76) \\
\end{array}$ \\
\hline Industry & Control & Control \\
\hline Year & Control & Control \\
\hline$N$ & 5988 & 5988 \\
\hline$r 2$ & 0.150 & 0.187 \\
\hline$r 2 \_a$ & 0.147 & 0.182 \\
\hline
\end{tabular}

$t$ statistics in parentheses; ${ }^{*} p<0.1,{ }^{* *} p<0.05$, and ${ }^{* * *} p<0.01$.

controlling for industry and year fixed effects only, and the regression coefficient of the explanatory variable CSR_Q is -0.0002 and significant at the $1 \%$ level, with an adjusted $R^{2}$ of 0.129 . Column (2) presents the regression results following the inclusion of all control variables. The regression coefficient of the explanatory variable CSR_Q is -0.0001 and still significant at the $1 \%$ level, with an adjusted $R^{2}$ of 0.177 , further supporting the previous empirical findings.

5.2. Measurement of the Replacement of the Quality of CSR Disclosure. In this paper, based on the method of Zou [15], according to the social responsibility disclosure data of the CSMAR database, a total of 12 articles are disclosed (specifically: whether to are audited by third-party institutions, whether to refer to GRI's Sustainability Reporting Guidelines, whether to disclose the protection of shareholders' rights and interests, whether to disclose the protection of creditors' rights and interests, whether to disclose the protection of employees' rights and interests, whether to disclose the protection of suppliers' rights and interests, whether to disclose customer and consumer rights protection, whether to disclose environmental and sustainable development, whether to disclose public relations and social welfare, whether to disclose social responsibility system construction and improvement measures, whether to disclose safety production content, and whether to disclose the company's deficiencies), each disclosure is assigned a value of 1 , no disclosure is assigned a value of 0 , and then the total score is divided by 12 to convert into a percentage. The closer the value is to 1 , the higher the quality of CSR information disclosure, and the variable symbol is set to CSR_Q1.

Prior to the regression analysis, the model was likewise retested for multicollinearity and it was found that the variance inflation factor (VIF) of all variables in the model was less than 10, indicating that the regression model did not have serious multicollinearity problems. Table 9 presents the regression results after replacing the quality measure of social responsibility information disclosure, where column (1) presents the regression results after controlling for industry and year fixed effects only, the regression coefficient of the explanatory variable CSR_Q1 is -0.0042 , and both are significant at the $1 \%$ level; column (2) presents the regression results after adding all control variables, the regression coefficient of the explanatory variable CSR_Q1 is -0.0017 and significant at the $10 \%$ level, and the overall research findings remain consistent with the previous paper.

5.3. Regression after First-Order Difference between Explanatory and Explained Variables. Theoretically, if the hypothesis holds, then the debt financing cost of enterprises will show an inverse change with the change of social responsibility disclosure quality score. Based on this, this paper conducts a first-order difference posterior regression on the variables of debt financing cost and social responsibility disclosure quality, with the variable signs set as D_Debt and D_CSR_Q, respectively, and with the regression model shown in

$$
D_{-} \text {Debt } \_C_{i, t}=\beta_{0}+\beta_{1} D_{-} \text {CSR }_{-} Q_{i, t}+\sum \beta_{i} \text { Control }_{i, t}+\varepsilon .
$$

Prior to the regression analysis, the model was likewise retested for multicollinearity and it was found that the variance inflation factor (VIF) of all variables in the model was less than 10, indicating that the regression model did not have serious multicollinearity problems. Table 10 presents the regression results after first-order differencing of the explanatory and explanatory variables, where column (1) presents the regression results after controlling only for industry and year fixed effects, and the regression coefficient of D_CSR_Q for social responsibility disclosure quality after first-order differencing is -0.00002 and is significant at the $5 \%$ level. Column (2) presents the regression results after adding all the control variables. The regression coefficient of D_CSR_Q for social responsibility disclosure quality after first-order differencing is -0.00001 and remains 
TABLE 5: Quality of social responsibility disclosure and cost of debt financing: analysis based on the nature of property rights.

\begin{tabular}{|c|c|c|}
\hline Variable name & $\begin{array}{c}\text { Group of non-SOE } \\
\text { Debt_C }\end{array}$ & $\begin{array}{c}\text { Group of SOE } \\
\text { Debt_C }\end{array}$ \\
\hline CSR_Q & $\begin{array}{c}-0.00019^{* * *} \\
(-8.903)\end{array}$ & $\begin{array}{c}-0.00005^{* * *} \\
(-3.000) \\
\end{array}$ \\
\hline Duality & $\begin{array}{c}0.00043 \\
(0.849)\end{array}$ & $\begin{array}{c}0.00092 \\
(1.221)\end{array}$ \\
\hline Indsize & $\begin{array}{c}0.00452 \\
(1.064) \\
\end{array}$ & $\begin{array}{c}-0.00522 \\
(-1.464)\end{array}$ \\
\hline Top1 & $\begin{array}{c}-0.00539^{* * *} \\
(-3.146) \\
\end{array}$ & $\begin{array}{c}-0.00684^{* * *} \\
(-4.611) \\
\end{array}$ \\
\hline Aud_Top10 & $\begin{array}{c}-0.00181^{* * *} \\
(-3.823)\end{array}$ & $\begin{array}{c}-0.00013 \\
(-0.294) \\
\end{array}$ \\
\hline Size & $\begin{array}{c}0.00033 \\
(1.398) \\
\end{array}$ & $\begin{array}{c}-0.00083^{* * *} \\
(-4.456) \\
\end{array}$ \\
\hline ROA & $\begin{array}{c}-0.00062 \\
(-0.330)\end{array}$ & $\begin{array}{c}-0.02683^{* * *} \\
(-5.152)\end{array}$ \\
\hline Lev & $\begin{array}{c}0.00656^{* * *} \\
(5.237) \\
\end{array}$ & $\begin{array}{c}0.00966^{* * *} \\
(6.144)\end{array}$ \\
\hline Growth & $\begin{array}{c}-0.00003 \\
(-1.184) \\
\end{array}$ & $\begin{array}{l}-0.00014 \\
(-0.725) \\
\end{array}$ \\
\hline Tangi & $\begin{array}{c}0.00281 \\
(1.234) \\
\end{array}$ & $\begin{array}{c}-0.00667^{* * *} \\
(-3.045)\end{array}$ \\
\hline $\mathrm{CF}$ & $\begin{array}{c}0.01371^{* * *} \\
(4.228) \\
\end{array}$ & $\begin{array}{c}0.02050^{* * * *} \\
(6.183) \\
\end{array}$ \\
\hline Loss & $\begin{array}{c}0.00326^{* * *} \\
(3.393)\end{array}$ & $\begin{array}{c}0.00161^{*} \\
(1.776)\end{array}$ \\
\hline _cons & $\begin{array}{c}0.02359^{* * *} \\
(3.877)\end{array}$ & $\begin{array}{c}0.05629^{* * *} \\
(11.604) \\
\end{array}$ \\
\hline Industry & Control & Control \\
\hline Year & Control & Control \\
\hline$N$ & 2934 & 3054 \\
\hline$r 2$ & 0.187 & 0.221 \\
\hline$r 2 \_a$ & 0.177 & 0.212 \\
\hline Suest test & \multicolumn{2}{|c|}{ Chi $2=24.96$ Prob $>$ Chi2 $=0.000$} \\
\hline
\end{tabular}

$t$ statistics in parentheses: ${ }^{*} p<0.1,{ }^{* *} p<0.05$, and ${ }^{* * *} p<0.01$.

significant at the $10 \%$ level, indicating that as the CSR disclosure quality score increases, an enterprise's debt financing cost decreases.

5.4. Explanatory Variables Lagged by One Period. For the control of the endogeneity problem due to reverse causality, the article reregressed the explanatory variables after a oneperiod lag. Prior to the regression analysis, the model was likewise retested for multicollinearity and it was found that the variance inflation factor (VIF) of all variables in the model was less than 10 , indicating that the regression model did not have serious multicollinearity problems. The regression results after lagging the explanatory variables by one period are presented in Table 11, where column (1) presents the regression results after controlling for industry and year fixed effects only, and the regression coefficient of social responsibility disclosure quality L_CSR_Q for the lagged period is -0.0001 and is significant at the $1 \%$ level. Column (2) presents the regression results after adding all the control variables. The regression coefficient of social responsibility disclosure quality L_CSR_Q for the lagged period is -0.0001 and is significant at the $1 \%$ level, further confirming the research hypothesis of this paper.

\section{Corporate Social Responsibility Disclosure, Debt Financing Costs, and Innovation Capacity: An Examination of the Economic Consequences}

Innovation has become the core driving force for China's high-quality economic development, from "developing the country through science and education" to building an "innovative country." Given this background, this section intends to further explore the economic consequences of CSR disclosure quality on the cost of debt financing from the perspective of corporate innovation. According to the theory, the negative effect of CSR disclosure quality on the cost of debt financing will lead to more low-cost cash flow, which 
TABLE 6: Quality of social responsibility disclosure and cost of debt financing: analysis based on the form of disclosure.

\begin{tabular}{|c|c|c|}
\hline Variable name & $\begin{array}{l}\text { Regulatory disclosure group } \\
\text { Debt_C }\end{array}$ & $\begin{array}{c}\text { Voluntary disclosure group } \\
\text { Debt_C }\end{array}$ \\
\hline CSR_Q & $\begin{array}{c}-0.00014^{* * *} \\
(-8.762)\end{array}$ & $\begin{array}{c}-0.00007^{* * *} \\
(-2.983)\end{array}$ \\
\hline SOE & $\begin{array}{c}-0.00066 \\
(-1.502)\end{array}$ & $\begin{array}{c}-0.00011 \\
(-0.140)\end{array}$ \\
\hline Duality & $\begin{array}{l}0.00010 \\
(0.206)\end{array}$ & $\begin{array}{c}0.00151^{*} \\
(1.735)\end{array}$ \\
\hline Indsize & $\begin{array}{c}-0.00500 \\
(-1.643)\end{array}$ & $\begin{array}{c}0.01511^{* *} \\
(2.493)\end{array}$ \\
\hline Top1 & $\begin{array}{c}-0.00628^{* * *} \\
(-4.863)\end{array}$ & $\begin{array}{c}-0.01085^{* * *} \\
(-4.816)\end{array}$ \\
\hline Aud_Top10 & $\begin{array}{c}-0.00107^{* * *} \\
(-2.880)\end{array}$ & $\begin{array}{c}-0.00061 \\
(-0.899)\end{array}$ \\
\hline Size & $\begin{array}{c}-0.00018 \\
(-1.104)\end{array}$ & $\begin{array}{c}-0.00074^{*} \\
(-1.952)\end{array}$ \\
\hline ROA & $\begin{array}{c}-0.00093 \\
(-0.553)\end{array}$ & $\begin{array}{c}-0.00887 \\
(-1.482)\end{array}$ \\
\hline Lev & $\begin{array}{l}0.00747^{* * *} \\
\quad(7.066)\end{array}$ & $\begin{array}{l}0.01154^{* * *} \\
\quad(4.782)\end{array}$ \\
\hline Growth & $\begin{array}{c}-0.00003 \\
(-1.243)\end{array}$ & $\begin{array}{c}-0.00040 \\
(-0.778)\end{array}$ \\
\hline Tangi & $\begin{array}{c}-0.00397^{* *} \\
(-2.305)\end{array}$ & $\begin{array}{c}0.00547 \\
(1.479)\end{array}$ \\
\hline $\mathrm{CF}$ & $\begin{array}{c}0.00979^{* * *} \\
(3.745)\end{array}$ & $\begin{array}{c}0.03188^{* * *} \\
\quad(6.448)\end{array}$ \\
\hline Loss & $\begin{array}{l}0.00372^{* * *} \\
\quad(5.102)\end{array}$ & $\begin{array}{c}0.00239^{*} \\
(1.773)\end{array}$ \\
\hline _cons & $\begin{array}{c}0.04143^{* * *} \\
(10.122)\end{array}$ & $\begin{array}{l}0.04552^{* * *} \\
\quad(5.106)\end{array}$ \\
\hline Industry & Control & Control \\
\hline Year & Control & Control \\
\hline$N$ & 4542 & 1446 \\
\hline$r 2$ & 0.187 & 0.222 \\
\hline$r 2 \_a$ & 0.180 & 0.203 \\
\hline Suest test & \multicolumn{2}{|c|}{ Chi $2=4.71$ Prob $>$ Chi $2=0.030$} \\
\hline
\end{tabular}

$t$ statistics in parentheses; ${ }^{*} p<0.1,{ }^{* *} p<0.05$, and ${ }^{* * *} p<0.01$.

can provide more financial support for innovative $R \& D$ and thus promote the innovation capability of enterprises. The following mediating effect model is further constructed in this paper to test whether the above theory is valid:

$$
\begin{aligned}
& \text { Innova }_{i, t}=\alpha_{0}+\alpha_{1} \text { CSR_Q }_{i, t}+\sum \alpha_{i} \text { Control }_{i, t}+\varepsilon_{i, t}, \\
& {\text { Debt_C } C_{i, t}}^{=} \beta_{0}+\beta_{1} \text { CSR_Q }_{i, t}+\sum \beta_{i} \text { Control }_{i, t}+\varepsilon_{i, t}, \\
& \text { Innova }_{i, t}=\gamma_{0}+\gamma_{1} \text { CSR_}_{-} Q_{i, t}+\gamma_{2} \text { Debt_C }_{i, t}+\sum \gamma_{i} \text { Control }_{i, t}+\varepsilon_{i, t} .
\end{aligned}
$$

In the above equation, Innova represents firm innovation, and following the example of Chen et al. [16], this paper measures the innovation capability of firms from two perspectives: input and output, respectively. For innovation inputs, we use firm R\&D expenditures divided by total assets to measure, and the variable is defined as RD. For innovation output, we measure the number of patent applications (Patenet_A) and the number of patents obtained (Patenet_G) separately and logarithmically. In addition, CSR disclosure quality (CSR_Q) is the explanatory variable, corporate debt financing cost (Debt_C) is the mediating variable, and Control is the control variable.
The regression results are shown in Table 12, columns (1) and (2) show the regression results of innovation input, firstly, the regression of social responsibility disclosure quality (CSR_Q) as the explanatory variable on the explanatory variable corporate innovation input $(\mathrm{RD})$, and the regression coefficient is significantly positive at the $1 \%$ level, indicating that the higher the quality of CSR disclosure, the higher the level of corporate innovation input. Second, the relationship between the variables of social responsibility disclosure quality (CSR_Q) and debt financing cost (Debt_C) has been proved in the previous section, and the regression coefficient is significantly negative, which is not shown here. As a final point, column (2) regresses the explanatory variable social responsibility disclosure quality (CSR_Q) and the mediating variable debt financing cost (Debt_C) with corporate innovation investment (RD) as the explanatory variable, and the coefficient of social responsibility disclosure quality (CSR_Q) is significantly positive at the $10 \%$ level and the coefficient of debt financing cost (Debt_C) is significantly negative, indicating that debt financing cost mediates between social responsibility information disclosure quality and corporate innovation 
TABLE 7: Quality of social responsibility disclosure and cost of debt financing: based on forensic effect analysis.

\begin{tabular}{|c|c|c|}
\hline Variable name & $\begin{array}{c}\text { Nonattestation group } \\
\text { Debt_C }\end{array}$ & $\begin{array}{c}\text { Attestation group } \\
\text { Debt_C }\end{array}$ \\
\hline CSR_Q & $\begin{array}{c}-0.00011^{* * *} \\
(-8.622)\end{array}$ & $\begin{array}{c}-0.00012^{*} \\
(-1.950)\end{array}$ \\
\hline SOE & $\begin{array}{c}-0.00073^{*} \\
(-1.934)\end{array}$ & $\begin{array}{c}-0.00838 \\
(-1.450)\end{array}$ \\
\hline Duality & $\begin{array}{c}0.00043 \\
(1.038)\end{array}$ & $\begin{array}{c}-0.00612^{*} \\
(-1.840)\end{array}$ \\
\hline Indsize & $\begin{array}{c}-0.00159 \\
(-0.573)\end{array}$ & $\begin{array}{c}0.01286 \\
(0.845)\end{array}$ \\
\hline Top1 & $\begin{array}{c}-0.00724^{* * *} \\
(-6.422)\end{array}$ & $\begin{array}{c}0.02909^{* *} \\
(2.006)\end{array}$ \\
\hline Aud_Top10 & $\begin{array}{c}-0.00105^{* * *} \\
(-3.194)\end{array}$ & $\begin{array}{c}0.00197 \\
(0.786)\end{array}$ \\
\hline Size & $\begin{array}{c}-0.00034^{* *} \\
(-2.284)\end{array}$ & $\begin{array}{c}-0.00507^{* * *} \\
(-3.548)\end{array}$ \\
\hline ROA & $\begin{array}{c}-0.00110 \\
(-0.676)\end{array}$ & $\begin{array}{l}0.01386 \\
(0.294)\end{array}$ \\
\hline Lev & $\begin{array}{l}0.00832^{* * *} \\
(8.519)\end{array}$ & $\begin{array}{c}-0.01258 \\
(-1.240)\end{array}$ \\
\hline Growth & $\begin{array}{c}-0.00003 \\
(-1.306)\end{array}$ & $\begin{array}{c}0.00745 \\
(1.317)\end{array}$ \\
\hline Tangi & $\begin{array}{l}-0.00146 \\
(-0.928)\end{array}$ & $\begin{array}{c}0.02073 \\
(1.075)\end{array}$ \\
\hline $\mathrm{CF}$ & $\begin{array}{c}0.01454^{* * *} \\
(6.269)\end{array}$ & $\begin{array}{c}0.05776^{* * *} \\
(3.141)\end{array}$ \\
\hline Loss & $\begin{array}{c}0.00380^{* * *} \\
(5.995)\end{array}$ & $\begin{array}{c}0.00438 \\
(0.727)\end{array}$ \\
\hline _cons & $\begin{array}{c}0.04203^{* * *} \\
(11.239)\end{array}$ & $\begin{array}{c}0.12571^{* * *} \\
(3.045)\end{array}$ \\
\hline Industry & Control & Control \\
\hline Year & Control & Control \\
\hline$N$ & 5905 & 83 \\
\hline$r 2$ & 0.188 & 0.750 \\
\hline$r 2 \_a$ & 0.182 & 0.634 \\
\hline Suest test & \multicolumn{2}{|c|}{ Chi $2=0.01$ Prob $>$ Chi $2=0.932$} \\
\hline
\end{tabular}

$t$ statistics in parentheses; ${ }^{*} p<0.1,{ }^{* *} p<0.05$, and ${ }^{* * *} p<0.01$.

investment; that is, social responsibility information disclosure quality can enhance corporate innovation investment through the path of reducing corporate debt financing cost. Likewise, columns (3) to (4) in Table 12 show the regression results for innovation output. It is clear that the results remain consistent whether the number of patent applications (Patenet_A) or the number of patents obtained (Patenet_G) is used as a measure of firm innovation output; that is, the cost of debt financing mediates the relationship between the quality of social responsibility disclosure and firm innovation output. Overall, the negative effect of CSR disclosure quality on the cost of debt financing promotes corporate innovation.

As a means of ensuring the robustness of the findings, the paper further employs the Sobel-Goodman test and Bootstrap test for the mediating effect, i.e., by directly testing the significance of the product of the coefficients $\beta 1$ and $\gamma 2$ (null hypothesis: $\beta 1 \gamma^{2}=0$ ). Table 13 presents the results of the Sobel-Goodman method for the mediating effect test, which shows that the mediating effect of debt financing cost (Debt_C) is significant at the $1 \%$ level, no matter whether the explanatory variable is RD, Patenet_A or Patenet_G, which represents that the representative debt financing cost mediates between the quality of social responsibility disclosure and the innovation capacity of the firm role.

Table 14 presents the results of the Bootstrap method's mediation effect test, which is estimated in this paper using regressions after 1,000 self-samplings, and again, the mediation effect holds significantly at the $1 \%$ level, no matter whether the explanatory variable is RD, Patenet_A, or Patenet_G. Overall, the test results remain consistent with the Sobel-Goodman method, and the findings of the study do not change substantially. 
TABLe 8: Robustness test 1: replacement of the debt financing cost measure.

\begin{tabular}{|c|c|c|}
\hline Variable name & $\begin{array}{c}(1) \\
\text { Debt_C1 }\end{array}$ & $\begin{array}{c}(2) \\
\text { Debt_C1 }\end{array}$ \\
\hline CSR_Q & $\begin{array}{c}-0.0002^{* * *} \\
(-14.29)\end{array}$ & $\begin{array}{c}-0.0001^{* * *} \\
(-8.46)\end{array}$ \\
\hline SOE & & $\begin{array}{c}-0.0015^{* * *} \\
(-3.70)\end{array}$ \\
\hline Duality & & $\begin{array}{c}0.0005 \\
(1.02)\end{array}$ \\
\hline Indsize & & $\begin{array}{c}-0.0039 \\
(-1.45)\end{array}$ \\
\hline Top1 & & $\begin{array}{c}-0.0051^{* * *} \\
(-4.12)\end{array}$ \\
\hline Aud_Top10 & & $\begin{array}{c}-0.0014^{* * *} \\
(-3.86)\end{array}$ \\
\hline Size & & $\begin{array}{c}-0.0010^{* * *} \\
(-5.90)\end{array}$ \\
\hline ROA & & $\begin{array}{c}0.0017 \\
(0.41)\end{array}$ \\
\hline Lev & & $\begin{array}{c}0.0114^{* * *} \\
\quad(5.72)\end{array}$ \\
\hline Growth & & $\begin{array}{c}-0.0000 \\
(-1.34)\end{array}$ \\
\hline Tangi & & $\begin{array}{c}-0.0024 \\
(-1.22)\end{array}$ \\
\hline $\mathrm{CF}$ & & $\begin{array}{c}0.0203^{* * * *} \\
(6.94)\end{array}$ \\
\hline Loss & & $\begin{array}{c}0.0045^{* * * *} \\
(5.07)\end{array}$ \\
\hline _cons & $\begin{array}{c}0.0363^{* * *} \\
(21.66)\end{array}$ & $\begin{array}{c}0.0555^{* * * *} \\
(13.37)\end{array}$ \\
\hline Industry & Control & Control \\
\hline Year & Control & Control \\
\hline$N$ & 5988 & 5988 \\
\hline$r 2$ & 0.133 & 0.182 \\
\hline$r 2 \_a$ & 0.129 & 0.177 \\
\hline
\end{tabular}

$t$ statistics in parentheses; ${ }^{*} p<0.1,{ }^{* *} p<0.05$, and ${ }^{* * *} p<0.01$.

TABLE 9: Robustness test 2: replacement of social responsibility information disclosure quality measures.

\begin{tabular}{|c|c|c|}
\hline Variable name & $\begin{array}{c}(1) \\
\text { Debt_C }\end{array}$ & $\begin{array}{c}(2) \\
\text { Debt_C }\end{array}$ \\
\hline CSR_Q1 & $\begin{array}{c}-0.0042^{* * *} \\
(-4.35)\end{array}$ & $\begin{array}{c}-0.0017^{*} \\
(-1.79)\end{array}$ \\
\hline SOE & & $\begin{array}{c}-0.0005 \\
(-1.41)\end{array}$ \\
\hline Duality & & $\begin{array}{c}0.0003 \\
(0.70)\end{array}$ \\
\hline Indsize & & $\begin{array}{c}-0.0013 \\
(-0.48)\end{array}$ \\
\hline Top 1 & & $\begin{array}{c}-0.0073^{* * *} \\
(-6.27)\end{array}$ \\
\hline Aud_Top10 & & $\begin{array}{c}-0.0011^{* * * *} \\
(-3.30)\end{array}$ \\
\hline Size & & $\begin{array}{c}-0.0005^{* * *} \\
(-2.95)\end{array}$ \\
\hline ROA & & $\begin{array}{c}-0.0019 \\
(-0.44)\end{array}$ \\
\hline Lev & & $\begin{array}{c}0.0085^{* * *} \\
\quad(5.15)\end{array}$ \\
\hline Growth & & $\begin{array}{c}-0.0000^{* *} \\
(-2.14)\end{array}$ \\
\hline
\end{tabular}


TABle 9: Continued.

\begin{tabular}{|c|c|c|}
\hline Variable name & $\begin{array}{c}(1) \\
\text { Debt_C }\end{array}$ & $\begin{array}{c}(2) \\
\text { Debt_C }\end{array}$ \\
\hline Tangi & & $\begin{array}{c}-0.0013 \\
(-0.74)\end{array}$ \\
\hline $\mathrm{CF}$ & & $\begin{array}{c}0.0135^{* * * *} \\
(4.77)\end{array}$ \\
\hline Loss & & $\begin{array}{c}0.0056^{* * *} \\
(6.67)\end{array}$ \\
\hline _cons & $\begin{array}{c}0.0313^{* * *} \\
(21.37)\end{array}$ & $\begin{array}{c}0.0400^{* * *} \\
(10.60)\end{array}$ \\
\hline Industry & Control & Control \\
\hline Year & Control & Control \\
\hline$N$ & 5988 & 5988 \\
\hline$r 2$ & 0.123 & 0.177 \\
\hline$r 2 \_a$ & 0.119 & 0.172 \\
\hline
\end{tabular}

$t$ statistics in parentheses; ${ }^{*} p<0.1,{ }^{* *} p<0.05$, and ${ }^{* * *} p<0.01$

TABLE 10: Robustness test 3: first-order difference between explanatory and explanatory variables.

\begin{tabular}{|c|c|c|}
\hline Variable name & $\begin{array}{c}(1) \\
\text { D_Debt_C }\end{array}$ & $\begin{array}{c}(2) \\
\text { D_Debt_C }\end{array}$ \\
\hline D_CSR_Q & $\begin{array}{c}-0.00002^{* *} \\
(-2.336)\end{array}$ & $\begin{array}{c}-0.00001^{*} \\
(-1.763)\end{array}$ \\
\hline SOE & & $\begin{array}{c}-0.00092^{* *} \\
(-2.565)\end{array}$ \\
\hline Duality & & $\begin{array}{c}0.00066 \\
(1.451)\end{array}$ \\
\hline Indsize & & $\begin{array}{c}0.00035 \\
(0.143)\end{array}$ \\
\hline Top1 & & $\begin{array}{c}0.00013 \\
(0.121)\end{array}$ \\
\hline Aud_Top10 & & $\begin{array}{c}0.00023 \\
(0.752)\end{array}$ \\
\hline Size & & $\begin{array}{c}0.00013 \\
(1.028)\end{array}$ \\
\hline $\mathrm{ROA}$ & & $\begin{array}{c}0.00059 \\
(0.184)\end{array}$ \\
\hline Lev & & $\begin{array}{c}0.00234^{*} \\
(1.662)\end{array}$ \\
\hline Growth & & $\begin{array}{c}0.00007 \\
(0.520)\end{array}$ \\
\hline Tangi & & $\begin{array}{c}-0.00286 \\
(-1.312)\end{array}$ \\
\hline $\mathrm{CF}$ & & $\begin{array}{c}-0.00349 \\
(-1.240)\end{array}$ \\
\hline Loss & & $\begin{array}{c}0.00211^{* * *} \\
(3.393)\end{array}$ \\
\hline _cons & $\begin{array}{c}0.00494^{* * *} \\
\quad(3.310)\end{array}$ & $\begin{array}{c}0.00316 \\
(0.894)\end{array}$ \\
\hline Industry & Control & Control \\
\hline Year & Control & Control \\
\hline$N$ & 3507 & 3507 \\
\hline$r 2$ & 0.066 & 0.080 \\
\hline$r 2 \_a$ & 0.059 & 0.070 \\
\hline
\end{tabular}

$t$ statistics in parentheses; ${ }^{*} p<0.1,{ }^{* *} p<0.05$, and ${ }^{* * *} p<0.01$. 
TABLE 11: Robustness test 4: lagging the explanatory variables by one period.

\begin{tabular}{|c|c|c|}
\hline Variable name & $\begin{array}{c}(1) \\
\text { Debt_C }\end{array}$ & $\begin{array}{c}(2) \\
\text { Debt_C }\end{array}$ \\
\hline L_CSR_Q & $\begin{array}{c}-0.0001^{* * *} \\
(-8.353)\end{array}$ & $\begin{array}{c}-0.0001^{* * *} \\
(-6.023)\end{array}$ \\
\hline SOE & & $\begin{array}{c}-0.0011^{* *} \\
(-2.357)\end{array}$ \\
\hline Duality & & $\begin{array}{l}0.0006 \\
(1.090)\end{array}$ \\
\hline Indsize & & $\begin{array}{c}-0.0061^{*} \\
(-1.833)\end{array}$ \\
\hline Top1 & & $\begin{array}{c}-0.0048^{* * *} \\
(-3.156)\end{array}$ \\
\hline Aud_Top10 & & $\begin{array}{l}-0.0005 \\
(-1.099)\end{array}$ \\
\hline Size & & $\begin{array}{c}-0.0008^{* * *} \\
(-4.520)\end{array}$ \\
\hline ROA & & $\begin{array}{l}0.0009 \\
(0.195)\end{array}$ \\
\hline Lev & & $\begin{array}{c}0.0078^{* * *} \\
(4.387)\end{array}$ \\
\hline Growth & & $\begin{array}{c}0.0001 \\
(0.284)\end{array}$ \\
\hline Tangi & & $\begin{array}{c}-0.0044^{*} \\
(-1.813)\end{array}$ \\
\hline $\mathrm{CF}$ & & $\begin{array}{c}0.0210^{* * *} \\
(6.018)\end{array}$ \\
\hline Loss & & $\begin{array}{c}0.0057^{* * *} \\
(5.944)\end{array}$ \\
\hline _cons & $\begin{array}{c}0.0389^{* * *} \\
(22.022)\end{array}$ & $\begin{array}{c}0.0595^{* * * *} \\
(12.964)\end{array}$ \\
\hline Industry & Control & Control \\
\hline Year & Control & Control \\
\hline$N$ & 3507 & 3507 \\
\hline$r 2$ & 0.145 & 0.196 \\
\hline$r 2 \_a$ & 0.139 & 0.188 \\
\hline
\end{tabular}

$t$ statistics in parentheses; ${ }^{*} p<0.1^{* *} p<0.05$, and ${ }^{* * *} p<0.01$

TABLE 12: Corporate social responsibility disclosure, cost of debt financing, and innovation capacity enhancement.

\begin{tabular}{|c|c|c|c|c|c|c|}
\hline Variable name & $\begin{array}{l}(1) \\
\mathrm{RD}\end{array}$ & $\begin{array}{l}(2) \\
\mathrm{RD} \\
\end{array}$ & $\begin{array}{c}\text { (3) } \\
\text { Patenet_A }\end{array}$ & $\begin{array}{c}(4) \\
\text { Patenet_A }\end{array}$ & $\begin{array}{c}(5) \\
\text { Patenet_G }\end{array}$ & $\begin{array}{c}(6) \\
\text { Patenet_G }\end{array}$ \\
\hline CSR_Q & $\begin{array}{c}0.00006^{* * *} \\
(3.614)\end{array}$ & $\begin{array}{c}0.00003^{*} \\
(1.855)\end{array}$ & $\begin{array}{c}0.00298^{*} \\
(1.688)\end{array}$ & $\begin{array}{l}-0.00010 \\
(-0.059)\end{array}$ & $\begin{array}{c}0.00310^{*} \\
(1.855)\end{array}$ & $\begin{array}{c}0.00023 \\
(0.142)\end{array}$ \\
\hline Debt_C & & $\begin{array}{c}-0.25127^{* * *} \\
(-13.427)\end{array}$ & & $\begin{array}{c}-22.63116^{* * *} \\
(-13.602)\end{array}$ & & $\begin{array}{c}-24.28771^{* * * *} \\
(-13.319)\end{array}$ \\
\hline SOE & $\begin{array}{c}-0.00152^{* * *} \\
(-2.746)\end{array}$ & $\begin{array}{c}-0.00190^{* * *} \\
(-3.545)\end{array}$ & $\begin{array}{l}0.04867 \\
(0.962)\end{array}$ & $\begin{array}{l}0.01150 \\
(0.233)\end{array}$ & $\begin{array}{l}-0.01253 \\
(-0.256)\end{array}$ & $\begin{array}{l}-0.04717 \\
(-0.986)\end{array}$ \\
\hline Duality & $\begin{array}{c}0.00157^{* * * *} \\
(2.862)\end{array}$ & $\begin{array}{c}0.00167^{* * *} \\
(3.109)\end{array}$ & $\begin{array}{c}0.09046^{*} \\
(1.718)\end{array}$ & $\begin{array}{c}0.10053^{*} \\
(1.949)\end{array}$ & $\begin{array}{c}0.03036 \\
(0.599)\end{array}$ & $\begin{array}{c}0.03975 \\
(0.794)\end{array}$ \\
\hline Indsize & $\begin{array}{c}0.01134^{* * *} \\
(3.075)\end{array}$ & $\begin{array}{c}0.01126^{* * *} \\
(3.100)\end{array}$ & $\begin{array}{c}1.10744^{* * *} \\
(3.240)\end{array}$ & $\begin{array}{c}1.09947^{* * *} \\
(3.293)\end{array}$ & $\begin{array}{c}1.21491^{* * *} \\
(3.566)\end{array}$ & $\begin{array}{c}1.20748^{* * *} \\
(3.600)\end{array}$ \\
\hline Top1 & $\begin{array}{r}0.00125 \\
(0.828)\end{array}$ & $\begin{array}{l}-0.00072 \\
(-0.482)\end{array}$ & $\begin{array}{c}-0.44037^{* * *} \\
(-2.946)\end{array}$ & $\begin{array}{c}-0.63081^{* * *} \\
(-4.197)\end{array}$ & $\begin{array}{c}-0.16701 \\
(-1.154)\end{array}$ & $\begin{array}{c}-0.34446^{* *} \\
(-2.366)\end{array}$ \\
\hline Aud_Top10 & $\begin{array}{c}0.00252^{* * * *} \\
(5.917)\end{array}$ & $\begin{array}{l}0.00216^{* * *} \\
(5.155)\end{array}$ & $\begin{array}{l}0.12881^{* * *} \\
(3.074)\end{array}$ & $\begin{array}{c}0.09380^{* *} \\
(2.280)\end{array}$ & $\begin{array}{c}0.11569^{* * *} \\
(2.844)\end{array}$ & $\begin{array}{c}0.08307^{* *} \\
(2.072)\end{array}$ \\
\hline Size & $\begin{array}{c}-0.00154^{* * *} \\
(-6.348)\end{array}$ & $\begin{array}{c}-0.00163^{* * *} \\
(-7.215)\end{array}$ & $\begin{array}{c}0.69032^{* * *} \\
(32.657)\end{array}$ & $\begin{array}{c}0.68194^{* * *} \\
(33.873)\end{array}$ & $\begin{array}{c}0.65259^{* * *} \\
(31.935)\end{array}$ & $\begin{array}{c}0.64479^{* * *} \\
(33.226)\end{array}$ \\
\hline ROA & $\begin{array}{c}0.00038 \\
(0.157)\end{array}$ & $\begin{array}{c}0.00059 \\
(0.241)\end{array}$ & $\begin{array}{c}-0.50541^{* *} \\
(-2.539)\end{array}$ & $\begin{array}{c}-0.48526^{* *} \\
(-2.438)\end{array}$ & $\begin{array}{c}-0.80459^{* * *} \\
(-4.504)\end{array}$ & $\begin{array}{c}-0.78582^{* * * *} \\
(-3.708)\end{array}$ \\
\hline
\end{tabular}


TABle 12: Continued.

\begin{tabular}{|c|c|c|c|c|c|c|}
\hline Variable name & $\begin{array}{l}(1) \\
\mathrm{RD}\end{array}$ & $\begin{array}{l}(2) \\
\mathrm{RD}\end{array}$ & $\begin{array}{c}\text { (3) } \\
\text { Patenet_A }\end{array}$ & $\begin{array}{c}(4) \\
\text { Patenet_A }\end{array}$ & $\begin{array}{c}\text { (5) } \\
\text { Patenet_G }\end{array}$ & $\begin{array}{c}(6) \\
\text { Patenet_G }\end{array}$ \\
\hline Lev & $\begin{array}{c}0.00028 \\
(0.108)\end{array}$ & $\begin{array}{c}0.00282 \\
(1.283)\end{array}$ & $\begin{array}{c}-0.40984^{* *} \\
(-2.403)\end{array}$ & $\begin{array}{c}-0.16356 \\
(-1.133)\end{array}$ & $\begin{array}{c}-0.35589^{* *} \\
(-2.130)\end{array}$ & $\begin{array}{c}-0.12641 \\
(-0.892)\end{array}$ \\
\hline Growth & $\begin{array}{c}-0.00004^{*} \\
(-1.656)\end{array}$ & $\begin{array}{c}-0.00005^{*} \\
(-1.807)\end{array}$ & $\begin{array}{c}-0.00790 \\
(-1.304)\end{array}$ & $\begin{array}{c}-0.00890 \\
(-1.469)\end{array}$ & $\begin{array}{c}-0.00809 \\
(-1.428)\end{array}$ & $\begin{array}{c}-0.00902 \\
(-1.575)\end{array}$ \\
\hline Tangi & $\begin{array}{c}0.00976^{* * *} \\
(4.310)\end{array}$ & $\begin{array}{c}0.01039^{* * *} \\
(4.592)\end{array}$ & $\begin{array}{c}0.47236^{* *} \\
(2.091)\end{array}$ & $\begin{array}{c}0.53306^{* *} \\
(2.389)\end{array}$ & $\begin{array}{c}0.62791^{* * *} \\
(3.038)\end{array}$ & $\begin{array}{c}0.68447^{* * *} \\
(3.373)\end{array}$ \\
\hline CF & $\begin{array}{c}0.00952^{* * *} \\
(2.777)\end{array}$ & $\begin{array}{c}0.01334^{* * *} \\
(3.986)\end{array}$ & $\begin{array}{c}0.08204 \\
(0.231)\end{array}$ & $\begin{array}{l}0.45141 \\
(1.308)\end{array}$ & $\begin{array}{c}-0.24749 \\
(-0.743)\end{array}$ & $\begin{array}{c}0.09670 \\
(0.295)\end{array}$ \\
\hline Loss & $\begin{array}{c}-0.00146 \\
(-1.640)\end{array}$ & $\begin{array}{c}-0.00054 \\
(-0.634)\end{array}$ & $\begin{array}{c}-0.26152^{* * *} \\
(-3.015)\end{array}$ & $\begin{array}{c}-0.17276^{* *} \\
(-2.035)\end{array}$ & $\begin{array}{c}-0.19573^{* *} \\
(-2.346)\end{array}$ & $\begin{array}{c}-0.11303 \\
(-1.380)\end{array}$ \\
\hline _cons & $\begin{array}{c}0.01480^{* * * *} \\
(2.832)\end{array}$ & $\begin{array}{c}0.02454^{* * *} \\
(4.858)\end{array}$ & $\begin{array}{c}-14.46588^{* * *} \\
(-28.110)\end{array}$ & $\begin{array}{c}-13.52361^{* * *} \\
(-26.661)\end{array}$ & $\begin{array}{c}-14.29706^{* * *} \\
(-28.968)\end{array}$ & $\begin{array}{c}-13.41906^{* * *} \\
(-27.675)\end{array}$ \\
\hline Industry & Control & Control & Control & Control & Control & Control \\
\hline Year & Control & Control & Control & Control & Control & Control \\
\hline$N$ & 4743 & 4743 & 4743 & 4743 & 4743 & 4743 \\
\hline$r 2$ & 0.262 & 0.294 & 0.360 & 0.387 & 0.355 & 0.380 \\
\hline$r 2 \_a$ & 0.256 & 0.288 & 0.355 & 0.382 & 0.350 & 0.375 \\
\hline
\end{tabular}

$t$ statistics in parentheses; ${ }^{*} p<0.1,{ }^{* *} p<0.05$, and ${ }^{* * *} p<0.01$.

TABLe 13: Sobel-Goodman test for mediating effects.

\begin{tabular}{|c|c|c|c|}
\hline Project & $\begin{array}{l}(1) \\
\mathrm{RD}\end{array}$ & $\begin{array}{c}(2) \\
\text { Patenet_A }\end{array}$ & $\begin{array}{c}(3) \\
\text { Patenet_G }\end{array}$ \\
\hline Sobel & $\begin{array}{l}0.0003^{* * *} \\
(7.752)\end{array}$ & $\begin{array}{c}0.0031^{* * *} \\
(7.702)\end{array}$ & $\begin{array}{c}0.0029^{* * *} \\
(7.614)\end{array}$ \\
\hline Goodman-1 & $\begin{array}{l}0.0003^{* * *} \\
(7.739)\end{array}$ & $\begin{array}{c}0.0031^{* * *} \\
(7.689)\end{array}$ & $\begin{array}{c}0.0029^{* * *} \\
(7.600)\end{array}$ \\
\hline Goodman-2 & $\begin{array}{c}0.0003^{* * *} \\
(7.766)\end{array}$ & $\begin{array}{l}0.0031^{* * *} \\
(7.716)\end{array}$ & $\begin{array}{c}0.0029^{* * *} \\
(7.628)\end{array}$ \\
\hline Mediation effect & $\begin{array}{c}0.0003^{* * *} \\
(7.752)\end{array}$ & $\begin{array}{c}0.0031^{* * *} \\
(7.702)\end{array}$ & $\begin{array}{c}0.0029^{* * *} \\
(7.614)\end{array}$ \\
\hline Direct effect & $\begin{array}{c}0.0032^{*} \\
(1.925)\end{array}$ & $\begin{array}{l}-0.0001 \\
(-0.042)\end{array}$ & $\begin{array}{l}0.0003 \\
(0.169)\end{array}$ \\
\hline Total effect & $\begin{array}{c}0.0064^{* * *} \\
(3.801)\end{array}$ & $\begin{array}{c}0.0031^{*} \\
(1.818)\end{array}$ & $\begin{array}{c}0.0032^{* *} \\
(1.960)\end{array}$ \\
\hline Observed values & 4743 & 4743 & 4743 \\
\hline Variable settings & $\begin{array}{l}\text { Mediated variables:Debt_C } \\
\text { Explanatory variables: CSR_Q }\end{array}$ & $\begin{array}{l}\text { Mediated variables:Debt_C } \\
\text { Explanatory variables: CSR_Q }\end{array}$ & $\begin{array}{l}\text { Mediated variables:Debt_C } \\
\text { Explanatory variables: CSR_Q }\end{array}$ \\
\hline
\end{tabular}

TABLE 14: Bootstrap mediated effect test.

\begin{tabular}{|c|c|c|c|}
\hline Project & $\begin{array}{l}(1) \\
\mathrm{RD}\end{array}$ & $\begin{array}{c}(2) \\
\text { Patenet_A }\end{array}$ & $\begin{array}{c}\text { (3) } \\
\text { Patenet_G }\end{array}$ \\
\hline Mediation effect & $\begin{array}{c}0.0003^{* * *} \\
(7.16) \\
\end{array}$ & $\begin{array}{c}0.0031^{* * *} \\
(7.05) \\
\end{array}$ & $\begin{array}{c}0.0029^{* * *} \\
(7.20) \\
\end{array}$ \\
\hline Direct effect & $\begin{array}{c}0.0003^{*} \\
(1.83)\end{array}$ & $\begin{array}{c}-0.0001 \\
(-0.04)\end{array}$ & $\begin{array}{c}0.0003 \\
(0.15)\end{array}$ \\
\hline $\begin{array}{l}\text { Observed values } \\
\text { Self-sampling times }\end{array}$ & $\begin{array}{l}4743 \\
1000\end{array}$ & $\begin{array}{l}4743 \\
1000\end{array}$ & $\begin{array}{l}4743 \\
1000\end{array}$ \\
\hline Variable settings & $\begin{array}{c}\text { Mediated variables:Debt_C } \\
\text { Explanatory variables: CSR_Q }\end{array}$ & $\begin{array}{c}\text { Mediated variables:Debt_C } \\
\text { Explanatory variables: CSR_Q }\end{array}$ & $\begin{array}{l}\text { Mediated variables:Debt_C } \\
\text { Explanatory variables: CSR_Q }\end{array}$ \\
\hline
\end{tabular}




\section{Conclusion and Contribution}

This paper empirically tests the impact of CSR disclosure quality on the cost of debt financing based on a sample of 5988 observations of Chinese A-share listed companies in Shanghai and Shenzhen from 2009 to 2018. According to the findings, (1) holding all other conditions constant, CSR disclosure quality is negatively related to debt financing cost, and this finding persists after adopting a replacement measure of debt financing cost, a replacement measure of CSR disclosure quality, and a robustness test that breaks down the evaluation dimensions of social responsibility disclosure quality. (2) In this paper, situational differences in the impact of social responsibility information disclosure quality on the cost of debt financing are examined under different property rights nature, different disclosure forms, and different forensic effects. The impact of social responsibility information disclosure quality on the cost of debt financing is found to be greater in the sample group of non-SOEs than in the sample group of SOEs, distinguishing between different property rights. The impact of social responsibility information disclosure on the cost of debt financing is found to be greater in the group of voluntary disclosure compared to the group of voluntary disclosure. Distinguishing different assurance effects, it is found that the impact of social responsibility information disclosure quality on the cost of debt financing is not significantly different between the assurance and nonassessment groups. (3) Furthermore, the paper investigates the economic consequences of CSR disclosure quality on the cost of debt financing from the perspective of corporate innovation. The results of the three-step mediating effect model and the Sobel-Goodman and Bootstrap tests find that the cost of debt financing mediates the relationship between the quality of CSR disclosure and corporate innovation inputs and outputs; that is, the quality of CSR disclosure can promote corporate innovation through the path of reducing corporate debt financing costs.

In this paper, the contributions mainly include: first, while the research on the cost of debt financing and innovation capability of enterprises is mainly from the perspective of profitability and financial information disclosure, this paper examines the economic consequences of corporate disclosure of social responsibility information from the perspective of corporate disclosure motives, thereby deepening the understanding of corporate disclosure motives of social responsibility. Secondly, with regard to the research on CSR and debt financing cost mainly examines the impact of postdisclosure on debt financing cost, this paper will deepen the examination of the impact of CSR disclosure, property rights nature, disclosure form, forensic results, and disclosure quality on debt financing cost, and further deepen the understanding of the relationship between CSR disclosure and debt financing cost. Third, the findings of this paper are of practical significance and of certain reference value in the formulation of policies on CSR disclosure [17].

\section{Data Availability}

The reader could access the data from the CSMAR database and CSR information disclosure data from RKS. We select
2009-2018 Chinese listed companies in Shanghai and Shenzhen A-shares as samples.

\section{Conflicts of Interest}

The authors declare that they have no conflicts of interest.

\section{References}

[1] Y. Wang and F. Jiang, "Can multiple large shareholders reduce the cost of corporate debt financing," World Economy, vol. 10, pp. 119-143, 2017.

[2] F. Modigliani and M. Miler, "The cost of capital, corporation finance and the theory of in- vestment," American Economic Review, vol. 48, no. 3, pp. 261-297, 1958.

[3] W. Zhang, X. Mao, and K. Liu, "Has interest rate market reform lowered the cost of debt financing for listed companies?" Journal of Financial Research, vol. 10, pp. 106-122, 2018.

[4] W. Liu, L. Chen, and Y. Cai, "Industry environment, audit opinion and cost of debt," Audit Research, vol. 3, pp. 80-86, 2018.

[5] X. Qian, Y. Tang, and F. Sheng, "Did the reform of the security interest system reduce the cost of corporate debt financing? Empirical evidence from a natural experiment of China's property law," Financial Research, vol. 7, pp. 115-134, 2019.

[6] X. Quan, S. Wu, and H. Yin, "CSR and stock price collapse risk: "Value tool" or "self-interest tool"?" Economic Research, vol. 11, pp. 49-64, 2015.

[7] C. Leuz and R. E. Verrecchia, "The economic consequences of increased disclosure," Journal of Accounting Research, vol. 38, no. 1, pp. 91-124, 2000.

[8] A. Goss and G. S. Roberts, "The impact of corporate social responsibility on the cost of bank loans," Journal of Banking \& Finance, vol. 35, no. 7, pp. 1794-1810, 2011.

[9] R. E. Verrecchia, "Essays on disclosure," Journal of Accounting and Economics, vol. 32, no. 1, pp. 97-180, 2001.

[10] Q. Zhou, L. Wang, J. Li, S. Zhou, and L. Li, "The study on credit risk warning of regional listed companies in China based on logistic model," Discrete Dynamics in Nature and Society, vol. 5, p. 8, 2021.

[11] H. Shen and J. Liao, "Accounting and the construction of ecological civilization system," Accounting Research, vol. 7, pp. 12-17, 2014.

[12] X. He, T. Xiao, and X. Chen, "CSR disclosure and corporate finance constraints," Financial Research, vol. 8, pp. 61-72, 2012.

[13] Y. Guo, C. Su, and Y. Zhang, "Does corporate social responsibility disclosure improve the company's market performance?" Systems Engineering-Theory \& Practice, vol. 39, no. 4, pp. 881-892, 2019.

[14] K. Zhou, Z. Ma, and L. Wu, "Executives' academic experience and the cost of corporate debt financing," Economic Research, vol. 7, pp. 169-183, 2017.

[15] P. Zou, "Regional economic development, socially responsible behavior and investment in science and technology innovation,” Scientology Research, vol. 5, pp. 922-932, 2018.

[16] K. Chen, Q. Wan, and Y. Kang, "State governance system and innovation efficiency of state-owned enterprises prises prises rprises rises rises ises ataection supervision," Naikai Business Review, vol. 41, no. 8, pp. 211-219, 2020.

[17] Q. Wu, A. Pan, and X. Liu, "Industrial policy support, firm life cycle and risk taking," Business Economics and Management, vol. 1, pp. 74-87, 2019. 